\title{
METHIMAZOLE IN THE TREATMENT OF LEPROSY
}

\author{
By S. G. Browne, M.D., F.R.C.P., F.R.C.S., D.T.M. \\ and \\ L. M. HOGERZEIL, MED., DRS., LEYDEN \\ Leprosy Service Research Unit, Uzuakoli, Eastern Nigeria
}

Methimazole (Tapazole, Lilly) has been used in the treatment of leprosy by Arturo O'Byrne González (1960; Leprosy Rev., 1961). This report concerns five adult patients who received the drug over a period of nine months at the Uzuakoli Settlement, Eastern Nigeria. The patients were unselected; all were suffering from severe lepromatous leprosy of two years' duration, two of them being relapsed cases.

\section{Previous treatment}

Before the beginning of the trial, four of the patients received small doses of dapsone for short periods (totals of 0.7 to $3.0 \mathrm{gr}$. in 5 to 10 weeks).

\section{Dosage}

All the patients received $5 \mathrm{mgm}$. of Tapazole orally three times a day, no other drug being given at the time. The average weight was $133 \mathrm{lbs}$. $(60 \cdot 5 \mathrm{~kg}$.), varying from $120 \mathrm{lbs}$. $(54.5 \mathrm{~kg}$.) to $140 \mathrm{lbs}$. $(63 \cdot 6 \mathrm{~kg}$.).

\section{Side effects}

Because of more or less severe side-effects, none of the patients was able to take the drug without interruption over the whole period of nine months during which the trial lasted. The average total interruption of treatment was six weeks.

The following complaints were noted: headache, general malaise, abdominal discomfort, nausea, generalized pruritus, restlessness, insomnia, vomiting, arthralgia, pain in metatarsals.

In view of the known toxic effects of methimazole and chemically related anti-thyroid compounds on the bone marrow (IRWIN et al. 1952; McGavack et al., 1954; Chevalley et al., 1954; British Med. $J .$, 1961), especially the risk of neutropenia and even agranulocytosis, total leucocyte counts and differential counts were made regularly (at first, every other day, and subsequently every week), the danger signals being a total leucocyte count below 3,000 per c.mm., or a percentage of polymorphonuclear cells below 30 .

At no examination was a severe degree of neutropenia observed, but on 36 occasions the percentage of granular cells was below 30 
(each of the five patients exhibiting this condition), and in one patient the total white cell count remained between 3,000 and 3,500 cells per c.mm. for several weeks. There was no observable effect on the erythrocytes or on the haemoglobin values. The Arneth count made from time to time showed no obvious deviation. No signs of hypothyroidism became apparent during the trial.

\section{Clinical results}

Two patients improved during the course of treatment, one of them markedly so; the lepromatous condition in the latter was complicated by borderline elements. Three patients were unimproved, one of them becoming definitely worse, with appearance of many new lesions and exacerbation of existing lesions.

\section{Bacteriological findings}

Examination of material obtained by the slit-smear method was made at fortnightly intervals from eight sites.

It will be noted that bacteriological improvement in patients numbers 1 and 4 did not run parallel with clinical improvement.

\begin{tabular}{|c|c|c|c|c|c|c|}
\hline \multirow[b]{2}{*}{$\begin{array}{l}\text { Serial } \\
\text { No. }\end{array}$} & \multicolumn{6}{|c|}{ Bacterial Index } \\
\hline & $\begin{array}{c}\text { Before } \\
\text { trial }\end{array}$ & $\begin{array}{c}\text { After } \\
2 \text { months }\end{array}$ & $\begin{array}{l}\text { After } \\
4 \text { months }\end{array}$ & $\begin{array}{c}\text { After } \\
6 \text { months }\end{array}$ & $\begin{array}{l}\text { After } \\
8 \text { months }\end{array}$ & $\begin{array}{l}\text { After } \\
10 \text { months }\end{array}$ \\
\hline $\begin{array}{l}1 . \\
2 . \\
3 . \\
4 . \\
5 .\end{array}$ & $\begin{array}{l}1.95 \\
3.0 \\
3.6 \\
2.75 \\
3.5\end{array}$ & $\begin{array}{l}1 \cdot 7 \\
2 \cdot 8 \\
3 \cdot 75 \\
2 \cdot 35 \\
3 \cdot 4\end{array}$ & $\begin{array}{l}1 \cdot 0 \\
2 \cdot 4 \\
3 \cdot 2 \\
0 \cdot 8 \\
3 \cdot 4\end{array}$ & $\begin{array}{l}1 \cdot 2 \\
2 \cdot 8 \\
3 \cdot 0 \\
0 \cdot 75 \\
3 \cdot 5\end{array}$ & $\begin{array}{l}1 \cdot 1 \\
3 \cdot 0 \\
2 \cdot 9 \\
1 \cdot 0 \\
3 \cdot 5\end{array}$ & $\begin{array}{l}1 \cdot 2 \\
3 \cdot 0 \\
3 \cdot 25 \\
0 \cdot 6 \\
3 \cdot 6\end{array}$ \\
\hline
\end{tabular}

The changes in bacterial morphology ran more or less pari passu with the Bacterial Index.

\begin{tabular}{|c|c|c|c|c|c|c|}
\hline \multirow[b]{3}{*}{$\begin{array}{l}\text { Serial } \\
\text { No. }\end{array}$} & \multirow[b]{3}{*}{$\begin{array}{l}\text { Lepromin } \\
\text { reaction }\end{array}$} & \multirow[b]{3}{*}{$\begin{array}{c}\text { Clinical } \\
\text { assessment }\end{array}$} & \multicolumn{4}{|c|}{ Bacterial Morphology } \\
\hline & & & \multicolumn{2}{|c|}{ Normal forms } & \multicolumn{2}{|c|}{ Acid-fast debris } \\
\hline & & & $\begin{array}{c}\text { Before } \\
\text { trial }\end{array}$ & $\begin{array}{l}\text { After } 10 \\
\text { months }\end{array}$ & $\begin{array}{c}\text { Before } \\
\text { trial }\end{array}$ & $\begin{array}{l}\text { After } 10 \\
\text { months }\end{array}$ \\
\hline 1. & & $\begin{array}{l}\text { Markedly } \\
\text { improved }\end{array}$ & $35 \%$ & $30 \%$ & $6 \%$ & $20 \%$ \\
\hline 2. & Doubtful & Stationary & $30 \%$ & $0 \%$ & $7 \%$ & $40 \%$ \\
\hline 3. & Negative & Stationary & $65 \%$ & $35 \%$ & $7 \%$ & $25 \%$ \\
\hline & & improved & $35 \%$ & $0 \%$ & $6 \%$ & $50 \%$ \\
\hline 5. & Negative & Worse & $50 \%$ & $50 \%$ & $15 \%$ & $10 \%$ \\
\hline
\end{tabular}

\section{Erythema nodosum leprosum}

Patient No. 5 had a persistent attack of erythema nodosum leprosum, which began after six months of treatment with the drug.

The erythrocyte sedimentation rate was in the main indicative of 
the observed clinical activity of the disease in the individual patient, declining consistently only in the Patient No. 1. There was a general slight fall in the E.S.R. during the first two months of treatment, followed by a gradual rise to the initial values and above.

\section{Conclusions}

On the clinical and bacteriological findings in this small series of cases treated for nine months with Methimazole, it is not considered that trials on a larger scale are indicated.

\section{Acknowledgements}

Our thanks are due to the World Health Organization, at whose suggestion the trial was conducted, to Messrs. Eli Lilly Research Laboratories for adequate supplies of Tapazole (their brand of Methimazole); and to Dr. S. E. Onwu, M.V.o., O.B.E., Director of Medical Services and Permanent Secretary, Ministry of Health, Eastern Nigeria, for permission to publish this article.

\section{Summary}

In Uzuakoli the authors made trial of Methimazole for 9 months on oral dosage of $5 \mathrm{mgm}$. t.d.s. with 5 adult patients with severe lepromatous leprosy of 2 years' duration. Severe side effects occurred and no patient could take the drug without interruption, the average total period of interruption being 6 weeks. Because of the known dangers of toxic effects on the bone-marrow, the authors made regular total leucocyte counts and differential counts. Severe neutropenia was not found, but on 36 occasions the percentage of granular cells was below 30 , and this occurred in each of the 5 patients. The Clinical Results were: improvement in 2 patients, marked in 1 of these. There was no improvement in 3 patients, and 1 of these became definitely worse.

The Bacterial Index improved in 2 cases but not in others, and there were changes in the bacterial morphology. Erythema nodosum leprosum occurred persistently in 1 patient. The E.S.R. declined consistently in 1 patient only.

The authors do not think that trials on a larger scale are indicated.

\section{References}

British med.J. (1961) Editorial, 1, 1520.

Chevalley, J., McGavack, T. H., Kenigsbery, S. and Pearson, S. (1954). J. Clin. Endocrin. Metab., 14, 948.

IRWIN, G. W., VAN VACTOR, H. D. and Norris, M. S. (1952) J.A.M.A., 149, 1637.

Leprosy Review (1961), Editorial, 32, 12.

McGavack, T. H. and Chevalley, J. (1954), Amer. J. Med., 17, 36.

O’BYRne, A. (1960) Internat.J. Leprosy, 28, 401. 